\title{
子どもの健康を守る健康心理学的介入 \\ 一一応用研究の意義と可能性について—— \\ Psychological intervention for promoting children's health: Significance and probability of applied studies
}

\author{
特集号編集委員 上地 広昭 大森 美香 \\ Special Issue Editors Hiroaki Uechi and Mika Omori
}

\begin{abstract}
アカデミズムの世界において応用性は長らく軽んじられてきた。英語圈最古の大学であるオックス フォード大学でさえ工学部が開設されたのは 20 世紀に入ってからのことである。学問とは崇高なもの であり，日常生活に近づくことは卑しいとされ，アカデミズムと実学は切り離されてきたのだ。20世 紀の偉大な数学者ゴッドフレイ・ハーデイは,「数学には二種類ある」と述べ, 真の数学と日常的な数 学の二つに分けた。美的感覚の鋭かった彼は, 弾道計算や航空力学などに応用された日常的な数学を

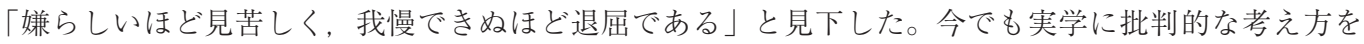
「ハーデイ主義」と呼ぶ。

このような考え方はいまだ根強く残っている。ポジティブ心理学の生みの親であるマーティン・セリ グマンの著書『ポジティブ心理学の挑戦』(原題：Flourish) の中でも以下のようなエピソードが紹介さ れている。彼が所属するペンシルベニア大学において, ポジティブ心理学の世間的な需要の高まりを受 けて新課程を設置する動きが出た。その際に, 大学側は既存の心理学部と差別化するために「A.」 (Applied；応用）を名前の頭に付けることを提案してきた。この提案に対し, 同僚の教授は「これは侮 辱的ではないか」とセリグマンに同情を寄せたという。つまり，「A.」が頭に付くということは学問と して一段低くみられていたということだ。しかし，セリグマンはこの「A.」を歓迎したという。むしろ， 何の役に立つのか分からないにもかかわらず，お高くとまっていた装飾的な（基礎）学問に対して彼は 憤っていたのだ。

本特集では「子どもの健康を守る健康心理学的介入」と題して, 子どもの心身の健康増進を目的とす る三つの応用研究 (介入研究) を揭載している。いずれの著者も, わが国の健康心理学領域に拉ける応 用研究のトップランナーである。本特集をご覧いただくことで, 確固たるエビデンスに基づく最新の心 理学的介入が, どれほど人々の健康に資するのかを理解してもらえるはずである。これらの介入研究で 得られた知見は，時を待たずして広く現場で応用されることだろう。健康増進という人類の至上命題に 対して, 応用性を高めていくことこそが健康心理学の強みである。本特集がその一端を担えていれば幸 いである。
\end{abstract}

